\title{
An overview of the Proposal of the Swedish Government Committee on Corporate Taxation
}

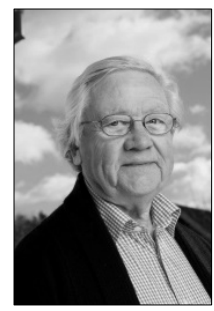

Professor Emeritus Sven-Olof Lodin Stockholm University

\section{Introduction}

On January 13, 2011, the Swedish Government appointed a special committee of inquiry into corporate taxation. According to the terms of reference of this government commission-the Committee on Corporate Taxation - it was entrusted with two main tasks:

1) develop a corporate taxation system that, to the greatest possible extent, should treat equity and borrowed capital equally within a framework of a reduction in the corporate tax rate; and to

2) introduce generally applicable legislation, in order to stop the ongoing erosion of the Swedish company tax base by international profit shifting, using interest payments to lenders in lowtax countries.

In addition to these two main tasks, the Committee was to propose legislation on tax incentives for equity investments in small companies by individuals and legislation on tax incentives for R\&D activities in small companies. A general condition for the work of the Committee was that all proposals should be financed within the system of 
corporate taxation (i.e. to be neutral with regard to the tax revenue of the Government).

Having presented proposals covering the equity incentives in January 2012 (SOU 2012:3) and the R\&D incentives in September 2012 (SOU 2012:66), the Committee presented its main report of 908 pages in June 2014 on the two main tasks (SOU 2014:40).

\section{Theoretical models for the neutral treatment of equity and borrowed capital}

In the traditional corporate tax systems, the costs of equity in the form of distribution of dividends to company shareholders are not deductible, whereas interest payments to lenders are deductible. In this way, the use of borrowed capital becomes cheaper than the use of equity and is often preferred by the company's owners, even in situations in which financial resources are available for equity investments. This also means that such investments as low-return real estate, that is accepted as collateral for loans, because of the leverage effect and strengthened by the tax deduction for interest costs will nevertheless generate a high rate of return on the small proportion of the equity capital invested by the owner. According to modern research in financial economy, this unequal tax treatment of the two financial resources for the working capital of a company leads to inefficient use of capital and lower productivity of the capital used.

In the theoretical tax discussion, two models exist for achieving tax neutrality between the use of equity and the use of borrowed capital: a) the method of Allowance for Costs of Equity (ACE) and b) Comprehensive Business Income Tax (CBIT). In its purest form, ACE grants the company a deduction for the part of the company profit corresponding to a risk-free return in the capital market. In CBIT, no deduction is given, either for costs of equity, such as dividends paid or for the interest cost on borrowed capital. The receiver will be taxed for the income, according to the same principle applied to all return on equity, even though no deduction is allowed for the cost of equity.

From the point of view of revenue, the cost of the deduction of a risk-free return on equity in the ACE method is relatively expensive and would probably necessitate a large increase in the corporate tax rate or dramatic broadenings of the tax base, in order to cover the drop of revenue for the state. That effect is extremely difficult to combine with the Swedish Government's desire for a reduced tax rate. Internationally, however, the ACE method is looked upon as an inter- 
esting model and two countries, Belgium and Italy, have introduced partial ACE methods in their company tax systems ${ }^{1}$.

In CBIT, the neutrality in treating equity and borrowed capital is achieved by disallowing any deduction either for equity costs or for the interest costs of borrowing. This model has two advantages. The resulting base broadening makes it possible to reduce the company tax rate considerably, while keeping the tax revenue unchanged. The other advantage is that all profit shifting by using interest payments to low-tax countries automatically becomes meaningless, as no interest deduction will be granted for any interest costs. That means that the other main goal according to the Government's directive is automatically taken care of by CBIT.

Two distinguished, internationally recognized economists-Ruud de Mooij of Erasmus University and Michael Devereux of Oxford University - have investigated several aspects of the macro effects of the two systems in a 2009 simulation study, covering 23 EU member states. $^{2}$

There are several primary results of this simulation. In many respect, the two systems yield different effects, depending on the economic status and degree of development of the states involved. This means that neither model is suitable to serve as a common EU model. The CBIT model is especially appropriate for states having an open economy, a large international sector, and sizable exports of sophisticated products and services. Sweden, having an export sector amounting to 50 per cent of GDP, is especially mentioned in the study as the EU country that would profit most by introducing the CBIT model; it should lead to clear welfare gains, a higher quality of investments, greater productivity, and better international competitiveness, in that they become highly attractive for high-profitability international investments. A simulation based on relatively rough historical data cannot be trusted to provide an accurate picture. The indications of the general directions and effects are clear and seemingly reliable, however.

1 See European Commission, Taxation and Customs Union DirectorateGeneral, Working Paper No. 44: Addressing the Debt Bias: A Comparison between the Belgian and the Italian ACE Systems. July 182014.

2 Alternative Systems of Business Tax in Europe - An applied analysis of ACE and CBIT Reforms. Ruud A. de Mooij and Michael P. Devereux, Taxation Paper, European Union 2009. 


\section{The model chosen by the Committee}

\subsection{A modified CBIT model}

As the CBIT model seemed to fit in well with both the main terms of reference given by the Government, the Committee chose to propose a modified version of the CBIT model, treating costs of equity and costs of foreign capital equally, thereby accounting for the specific conditions relevant to Sweden. The two main modifications of the model are:

a) In order to simplify the difference between deductible and nondeductible costs, no deduction will be allowed for cases in which financial costs exceed the financial income of a company. (These are labeled negative financial items because financial costs can be offset against financial income, but costs above that will be nondeductible against other income.) This means that interestlike financial costs or costs in connection with a loan and the interest component of a periodic payment (e.g. of a leasing costwith the exemption of normal rent for real estate) will not be deductible against income other than financial income. But the widening of the concept to all financial costs also means that some financial items will be nondeductible. Examples would include capital losses on shares and other financial instruments and losses or costs on foreign currency transactions, with a special rule allowing deductions for currency costs and losses that are directly connected to trade or the like. Within groups of companies in which financial integration exceeds 90 per cent, this offset should be made on a group basis in order to avoid disadvantages for enterprises comprising several companies, as compared to enterprises in which the entire business is within a single company.

b) The base-broadening effect would allow a tax rate reduction from the existing 22 per cent down to 16.5 per cent, giving the Government the same revenue as in today's system. Instead of reducing the nominal tax rate of 22 per cent, however, the Commission proposes a general "financing allowance" of 25 per cent of the taxable income. Thus the nominal tax rate of 22 per cent will still be applied, but to only 75 per cent of the taxable income, which, for all practical purposes, equals a tax reduction to an effective tax rate of 16.5 per cent. The rationale for this allowance is that the tax rate should remain above 20 per cent in order to avoid international attacks from other governments on the formal tax rate. To some extent, this is purely psychological, aimed 
at demonstrating that it equals a deduction for interest costs up to 25 per cent of the income.

The overall effect of the model is that equity and borrowed capital are treated equally; the more favorable tax treatment of borrowed capital over equity is abolished. In modern financial economy research, this result is considered to be an important quality for achieving a more efficient use of capital. ${ }^{3}$ The system also eliminates all incentives to international tax arbitrage by way of international loan transactions. The specific existing restrictions on the deductibility of interest costs and profit shifting, including the highly uncertain rules for deductibility that demand the business purpose of loans being irreplaceable by equity, for example, can be totally abolished, eliminating an area of great uncertainty and providing a significant simplification to the Swedish system of corporate taxation.

\subsection{Effects on interest costs after tax}

The reduced effective tax rate of 16.5 per cent will result in a limited increase in borrowing costs on that part of the cost not possible to offset financial income. At a 5 per cent interest rate, the increase in the after-tax loan cost is limited to 0.825 per cent-less than a 1 per cent increase of the after tax cost. At the low interest rate of approximately 3 per cent in 2014-2015, the increased after-tax costs of an interest payment is limited to only 0.485 per centage points. These increases are not larger than those normally caused by market-rate fluctuations.

It is important to note that a company with a high degree of borrowed capital does not necessarily pay a higher company tax than it would have had to pay before the reform. Rather, the decisive factor is the relationship between a company's return on working capital and the level of interest costs. If the rate of return is larger than the interest level, the company can often gain on the reform.

The following example, using an interest rate of 5 per cent, will demonstrate how high the possible loan level at that interest rate can be at different levels of return on working capital, without the compa-

3 Gertler, Mark, \& Glenn Hubbard, 1993, "Corporate Financial Policy, Taxation, and Macroeconomic Risk", RAND Journal of Economics, 24 (Summer 1993): 286-303.

Hubbard, Glenn, 1993, “Corporate Tax Integration: A View From the Treasury Department", The Journal of Economic Perspectives, Vol. 7, No. 1 (Winter, 1993), pp. 115-132.

See also Ruud de Mooij \& Michael Devereux, 2011. “An applied analysis of ACE and CBIT reforms in the EU", International Tax and Public Finance, Springer, vol. 18(1), p. 93-120. 
ny incurring a higher tax bill in the new 16.5 per cent tax rate compared to the existing classical company tax system of 22 per cent.

At a 5 per cent return on working capital after the tax reform, the company can incur a possible 25 per cent level of borrowing without having to pay more tax.

At a 10 per cent return on working capital, the company's possible loan level without increasing its tax burden is increased to 50 per cent.

At a 15 per cent return on working capital, the possible loan level without incurring a higher tax burden is increased to 75 per cent.

At lower loan levels, the company will pay lower tax in the new system. At today's interest rate of 3 per cent, a company can incur an even higher loan level and still be a winner under the tax reform. For companies with large loans, however, the new neutral treatment of equity and borrowed capital, implying loss of the privilege of deducting financial net costs, will mean that the gain due to the rate reduction will still be lower than will be the gain for companies financed mainly by equity.

\subsection{Effects for different lines of business and different types of companies}

Looking at the effects on different types of companies and lines of business, small- and medium-sized companies and new companies in general will gain from the reform, mainly because they have a lower debt/equity ratio than larger companies do, according to company statistics, as they have difficulty obtaining bank loans. Another indication in the same direction is that their share of total corporate tax is twice as great as their share of total debt. This means that they gain more on the reduction of the tax rate from 22 to 16.5 per cent than they lose due to the denial of deductions for negative financial items.

With regard to the effects on different lines of business, no industry is hit seriously by base broadening combined with the tax-rate reduction. The real-estate industry, especially companies with large investments in commercial real estate, is the only line of business that will suffer any substantial increase in its tax burden: approximately SEK 3.2 billion. About 1.2 billion of this amount will fall on rental housing. On the other hand, the tax burden on the real-estate industry is extremely favorable compared to the burden experienced in other lines of business. Thus, privately owned real-estate companies have, on average, a tax burden of less than 10 per cent of the income according to their accounts, whereas other industries have an average effective tax burden of approximately 20 per cent. Although this favorable result is the effect of the right to deduct loan interest and the combination of the leverage effects of their high loan/equity ratio and the deductions of interest costs, there is an additional benefit. The key factor is the 
possibility of selling real estate free of tax without any capital gains tax if the real estate is transferred to a subsidiary before the sale. This result occurs because, in order to avoid double taxation within the company sector, gains on so-called business-related shares, typically subsidiaries, are not taxable for the selling company. For several mainly technical reasons this possibility is kept in the new system. The average effective tax burden on the real-estate industry will increase to approximately 12-13 per cent, however, bringing their tax burden somewhat closer to the average tax that other companies are required to pay.

The reform may cause one severe problem for the real-estate industry, however - an issue that may have to be dealt with. Because of high building costs, rent regulations, and market conditions, the reform will make the building of new rental housing less profitable or even cause losses; at the same time there is a severe shortage of rental flats, especially in the larger cities. Under those conditions, politicians generally try to encourage the industry to build more rental housing. Thus more liberal transition rules could be desirable for this special kind of industrial activity. Retaining the right to deduct interest costs directly connected to the construction of new rental flats for a limited period, for example, would probably solve the problem.

Looking at the effects for other industries, it seems that the reform will probably provide the building sector with a slightly lower tax burden than it experiences today. The manufacturing industry, including mines, will probably gain approximately SEK 4 billion on the reform and trade and service industries SEK 3 billion. Most companies in investment-heavy industries will find that their tax burden is either unchanged or slightly lower than it was. And as for the 20 biggest exporting companies, they will all gain a little on the reform.

Large private companies within the health and eldercare sectors will experience a tax increase of approximately SEK 600 million. For other industries, the average effects of the transition to the new system will be minor. Not all types of tax effects can be allocated to specific industries (e.g. leasing costs), which explains why allocated increases and reductions of the tax burden for different lines of business do not correspond.

\section{The transition to the new system}

The estimations outlined above are based on the composition of income of various industries for 2012, assuming that the new system had been in full effect for some years without any adjustment in company behavior. It is important to investigate the transition problems 
that may occur, however. One such problem for the building of new rental flats has already been described in 3.3. The combination of disallowing negative financial items and reducing the tax rate to 16.5 per cent means that for most companies the transitional effects will be small. But for companies with a high debt ratio and large interest costs, the tax increase can be substantial. This also means that what would be a loss in the existing system because of high interest deductions could be transformed into taxable income because the ability to deduct net financial costs is prohibited. This can lead to unexpected liquidity problems unless some method of moderating the immediate effect exists.

The possibility of a postponement already exists in the present corporate tax system for taxation of a portion of the annual income for a period of up to six years, by setting funds aside in a tax allocation reserve (periodiseringsfond), up to 25 per cent of the taxable income of a specific year. A low interest rate will have to be paid for this postponement of taxation, however. This possibility, in combination with the financing allowance of 25 per cent of the taxable income, will mean that taxation of 43.75 per cent of taxable income will be deducted or postponed for a period of up to six years. Moreover, losses from earlier years can be deducted against the taxable income and can also be used to offset the increase of taxable income because of the denial of interest deduction. In combination, these three factors have led the Committee to conclude that no transitional rules would be necessary, except in two areas.

One exception has to do with the effects of the tax allocation reserve. Funds that have been allocated to the reserve before the tax reform comes into force have postponed taxation at the rate of 22 per cent (or even 26.3 per cent if the amount was set aside before 2013). As the new rate will be reduced to 16.5 per cent, old allocations would be taxed at a lower tax rate than the one in force when the allocation was made. In order to stop this windfall gain the Committee proposes that 133 per cent of old allocations will be taxable. This transitional rule will yield the same tax burden as the tax rate at the time the allocation was made.

The second area concerns old losses from the time before the introduction of the new system, as discussed in Section 7. The Committee proposes that the new system should, in all other respects, be fully introduced by the 1 January 2016. This means, however, that the problems concerning the building of new rental flats remain unsolved according to the proposal of the Commission, unless changes are made in the Government bill. 


\section{An extra tax on parts of the financial sector}

The basic idea of the reform proposed is to achieve neutrality in the treatment of equity and borrowed capital and to improve the situation for cases using equity financing. Against that background, it would have been strange under the reform if the financial sector-in particular the banks, which use a higher proportion of borrowed capital in their business than any other business sector-had been favored more than any other sector. This would have happened in the construction of the new company tax system chosen by the Committee, allowing positive financial items to be included as the basis of the financing allowance, unless some step had been taken to block such a development. Thus, the Committee proposes the introduction of a special compensating tax of approximately SEK 4 billion, on the same basis as the so-called stabilization fee on the value of bank lending stock that was introduced a few years ago in order to stabilize the banks' power to resist a financial crisis. The consequence of this proposal is that the introduction of the new tax system will be cost neutral for the banking sector, and the total tax burden for banks will be in line with the average tax burden of the total corporate sector.

\section{International issues}

One conclusion of the Mooij-Devereux study is that the introduction of this type of corporate tax system would probably make Sweden more attractive for profitable international investments. But will the reduction of the effective company tax rate result in international criticism from other countries? There are no real reasons for such criticism, as a broadening of the corporate tax base has financed the reduction of the tax rate. Such a reform is allowed according to the EU Code of Conduct. The reform will not result in a lower Swedish effective tax burden than in many of the EU member states and of other competing states. Another concern is that the use of equity will finance foreign investments in Sweden to a greater extent than before the reform, whereas foreign investors will use other group companies to borrow elsewhere in order to finance the Swedish equity investment. This effect does not violate any international rule or agreement. The only method of "retaliation" for any state seems to be an introduction of a similar system of its own.

Some experts claim that the new model will lead to extensive international double taxation, as interest payments of internal group loans taken by Swedish subsidiaries of foreign groups will be taxable in the receiving company, although no deduction will be granted in Sweden. 
One should keep in mind, however, that the different systems of limiting the right to deduct interest costs introduced in many countries will have almost the same effect, as the financing allowance in Sweden will be equivalent to a deduction for interest net costs of 25 per cent of the income-not far from the ceiling of 30 per cent in more traditional systems of limitations on interest deductions aimed at stopping international profit shifting by way of interest payments. The proposed Swedish model has a more systematic and theoretically balanced approach - neutral treatment of equity and borrowed capital-in line with modern economic research.

Some large international companies that conduct business in Sweden and some international tax experts who have had the opportunity to analyze the proposal have not perceived these international disadvantages for their Swedish operations. Rather, they claim that this new system will make Sweden a more attractive place for investment.

\section{Special issues of the proposal being criticized}

As previously mentioned, the absence of special transition rules for the construction of new rental flats has been subject to intensive criticism by real-estate companies. But there are a few other areas that have already been criticized within the Committee and from outside commentators after the publication of the Committee Report.

a) Companies that would have had little opportunity to use old losses from earlier years because of high interest costs against future income in the old system will, during the first years in the new system, be able to use these old losses against the increased tax burden of the new system. According to an analysis of this phenomenon, the new system will result in large revenue losses for the Government during the first few years - a situation that would violate the idea of revenue neutrality of the change to the new system. In order to prevent this development, the Committee has decided to reduce to onehalf the possibility of taking deductions for old losses incurred prior to the introduction of the new system. According to many commentators, this decision will yield retroactive effects in a way that should not be allowed in a state governed by law, however, and which will seriously damage the international reputation of stability and predictability that the Swedish tax system has enjoyed so far.

Furthermore, formal retroactivity is forbidden according to the Swedish Constitution. Although this limitation of the right to make a full deduction may not be a formal retroactivity according to the Constitution, the effects are exactly the same as a forbidden formal retroactivity. For these reasons, my view is that it should not be intro- 
duced. I have criticized this proposal in a special opinion enclosed in the Committee report.

Moreover, the problem is, to a great extent, merely a problem of periodicity. It could be possible to limit the amount that is allowably deducted against income during the first years under the new system. One way could be to limit the deductible part of old losses to 25 per cent per year during the first 4-5 years of the new system. A smaller revenue loss would remain, but it should be possible to cover that by using less dramatic methods.

b) In order to prevent the possibility of circumventing the prohibition against deducting interest costs or net financial costs within the corporate sector, the Committee has proposed that not only companies, but also partnerships, should not be allowed to deduct negative financial items. This causes two severe problems for individuals as owners of partnerships.

Because partnership income is taxed at the owner level, this income will be taxed as personal income at tax rates including social fees up to 67 per cent of the income for individuals owning shares in partnerships. Thus the income increase caused by the loss of the deduction for negative financial items will be taxed at 67 per cent compared to the company tax level of 16.5 per cent. In contrast, a company in a partnership will be taxed for its share of the partnership income, including the income increase because of the denied deduction at a tax rate of 16.5 per cent. This difference cannot be considered as fair taxation. Moreover, there is no sound reason to include all partnerships, including partnerships having no connection with any company.

As a matter of fact, the proposed rule is a clear overreaction, and sharp criticism has been raised against this rule-a criticism that was also raised in my special opinion enclosed in the Committee report. This criticism is particularly relevant given that an individual with shares in a partnership will receive no extra advantage over any other individual owning shares in an ordinary company. Both will have the possibility of borrowing capital to invest in a company and still be allowed a personal interest deduction. The only situation in which a shareholder in a partnership can have an extra advantage is if the partnership is a limited partnership with a company as the General Partner with unlimited liability. This construction implies that the general partner is fully responsible for all debt and interest costs of the partnership, which, in turn, means that the limited partner can avoid personal responsibility for his/her share of the costs. The proposed rule should, according to my view therefore be limited to limited partnerships that have a company as the general partner. 
c) The existing legislation limiting the right for a company with old losses to deduct these losses against income after the entrance of new majority owners was tightened by new rules in 2008. In practice, these new rules proved to be unintentionally harmful to R\&D and to innovative companies needing new capital in order to continue their activities. The Committee declared that the new rules needed to be reformed in order to make it easier for these companies to deduct old losses, in spite of the entrance of new majority shareholders. The proposed relief rules do not result in any real relaxation of the rules, however. In practice, the proposal mainly pays lip service to the intent, and must be further liberalized. Research-oriented enterprises, especially within the life-science sector, have sharply criticized the proposal as inadequate. The same criticism is included in my special opinion enclosed in the Committee report.

\section{Concluding remarks}

The idea of the tax reform is to achieve a more efficient allocation and use of capital by treating equity and borrowed capital neutrally. In combination with the reduced company tax rate, made possible by base broadening due to the disallowance of deductions for negative capital items, this will strengthen Sweden's competiveness and attract more foreign investment, which, in turn, should increase growth and welfare. The construction of the reform will also automatically stop the possibility of international profit shifting by way of loan transactions with companies in low-tax countries and stop the erosion of the Swedish tax base that has become a serious problem in recent years.

The construction of the proposal, which is based on modern economic research, will simplify Sweden's company tax system. It is a brave proposal, as this model has not yet been used elsewhere. However, the 1991 Swedish reform was more radical than any reform in other developed countries, and it was also viewed as brave and farsighted at the time. Many countries followed suit, and introduced similar tax models. Now Sweden is in the forefront once more. We will see the extent to which other countries will follow the Swedish example this time, in order to obtain a fairer, more effective, and growth-friendly corporate tax system. 